\title{
Derrida in memoriam
}

\section{Av Vasilis Papageorgiou}

\author{
Länk till presentation av Vasilis Papageorgiou
}

Nu är också Jacques Derrida borta. Efter de goda vännerna Emmanuel Levinas och Maurice Blanchot blev det hans tur att lämna oss. Alla tre har tagit läsandet av texter till för vår tid nya och avgörande kritiska riktningar. Och alla tre har skrivit om döden eller tolkat döden som en omöjlighet, dess förhållande till närvaron och frånvaron. Men oavsett hur man läser och tolkar döden blir sorgen aldrig mindre, det är inte heller tolkningens avsikt. Jag kände och känner fortfarande en stor sorg över Derridas bortgång den 8 oktober 2004. Jag har läst hans texter sedan början av 80-talet. Det blev många böcker under årens lopp, över sjuttio. Han skrev fortare än jag hann läsa. Men jag läste honom intensivt och ofta, efter hans exempel, kritiskt.

Det är det som är en av Derridas gåvor till sin tids oroliga och nyfikna intellektuella, att läsa, tänka och skriva kritiskt. Det som skall kritiseras är alla möjliga och omöjliga metafysiska påståenden, allt som begränsar med hjälp av givna sanningar, uppfattningar om olika identiteter, strukturer och hierarkier som är beroende av och genererar makt och maktfullkomlighet.

Derridas tänkande är ett grundläggande politiskt tänkande. Dess mål är friheten från det som begränsar och fängslar. Han är den store skeptikern i vår tid, den som ständigt och kompromisslöst ifrågasätter allt som använder, är beroende av och uttrycker makt. Och det gör alla påståenden, hierarkier, föreställningar om sanning och identitet.

Han har skapat den term och den kritiska verksamhet som kallas dekonstruktion. Dekonstruktion är inte någon metod, den kan inte sammanfattas och därför inte användas som ett verktyg. Dekonstruktion är en kritisk hållning som är beroende av det som ska plockas isär och kritiseras för att avslöja den makt som håller det samman och skänker det en till synes oproblematisk legitimitet. Det finns otaliga former av dekonstruktion, eftersom det finns otaliga former av makt, av metafysiska påståenden, av auktoritära definitioner.

Det är ett mysterium för mig att det inte finns fler böcker av Derrida på svenska. Kanske handlar det inte om något mysterium alls, men detta är en annan historia. Derrida är en vår tids största tänkare, ja en av den västerländska filosofins största tänkare. Och en av de mest kontroversiella, precis som Sokrates, Nietzsche eller Wittgenstein. Den som ifrågasätter allting kompromissar aldrig, och denna kompromisslöshet skapar kontroverser. Men Derrida är egentligen en stor samtalare. Han har samtalat med filosofer, skönlitterära författare, konstnärer. Han har låtit filosofin samtala med skönlitteraturen och tvärtom. Han har varit verksam inom olika universitet och ändå strävat att öppna universitetets och den institutionella kunskapens gränser. Han har alltid ansträngt sig att överskrida filosofins språk, ett enligt honom maskulint medium, ett maskulint logos, ett maktens verktyg.

Detta kritiska tänkande är också ett moraliskt tänkande. Det är ett ansvarsfullt tänkande på minst tre olika sätt. Det första sättet avser det som ska analyseras och kritiseras. Det andra sättet avser hur analysen och kritiken ska utformas, dekonstruktionens språk. Det tredje avser det som är marginaliserat eller anses vara den svagare sidan i ett polariserat förhållande. Jag börjar med det tredje. En student frågade mig en gång om man vid Växjö universitet får samma kunskaper som man får i Lund, om det som man läser i Växjö är på samma nivå som det som man läser i Lund. Här skulle Derrida skriva en text som utgår från följande kritiska frågor: 
Vad är ett universitet? Vad är ett litet och vad är ett stort universitet? Vad är kunskap? Vem är det som ställer dessa frågor? När frågar man? Hur frågar man? Var frågar man? Vem frågar man? På vilket eller vilka språk frågar man?

Detta sätt att ställa frågor har inte endast varit avgörande för filosofin och litteraturen utan även för en rad andra discipliner som antropologi, konst, historia, arkitektur, kvinnoforskning, queer studies, postkoloniala studier, minoritetsstudier.

Det första sättet har att göra med det som Derrida har valt att dekonstruera: idéer, föreställningar, uppfattningar, strukturer, termer, definitioner, auktoritära påståenden. Under senare år har denna verksamhet utöver filosofiska ämnen även riktat sig till direkt politiska företeelser som apartheid och Europas roll gentemot USA som mer och mer avlägsnar sig från de demokratiska principer som det säger sig stå för. Derrida var aktiv i studentrevolten i Paris 1968, var med och grundade en anti-apartheidstiftelse och en författarrörelse för Nelson Mandela.

Det andra sättet har att göra med hur Derrida kritiserar, vilket språk denna kritik använder. Derrida skapar medan han skriver samtidigt som han med stor respekt utgår från det språk som används i den text han skriver om. Analys och respekt är oskiljbara, de befruktar och inspirerar varandra. Derrida undviker att förvandla sitt språk till ett maktens verktyg; han vill inte generera makt och således begränsa det han strävar efter att öppna. Därför bygger han inte upp en metod, ett system av tankar. Detta gör att det analytiska ansvaret blir större, sättet på vilket han närmar sig det andra präglas av den moraliska plikten att inte tillägna sig eller göra våld på det andra.

Det har medfört att Derrida har utvecklat olika språkstilar, beroende på vad han skriver om. Detta är den andra gåvan han har givit oss. Ett rikt, vackert språk, många stilar som med briljans, entusiasm, tålamod, ihärdighet, enastående exakthet låter sig sammanflätas med andra texter och ändå behåller sin alldeles egen textur. Detta sätt att skriva får euforiska dimensioner i texter, där Derrida analyserar utan att kritisera deras tankegångar. Det ser vi när han skriver om Maurice Blanchot eller Antonin Artaud, författare som Derrida ser som inspirationskällor, som redan har varit i den öppenhet Derrida vill skapa.

Denna öppenhet är en annan gåva Derrida har givit oss. Att inte vara rädda att komma in på olika områden, att inte ta gränserna mellan olika områden som något givet, bortom vår ifrågasättande granskning.

En annan gåva är hans lust att skapa, hans energi, hans unika nyfikenhet som har lett till så många olika böcker som utforskar olika humanistiska områden.

Jag vill avsluta med en bejakande Derrida, en som njuter av sitt eget språk. Inte alla hans texter är kritiska, som sagt, även om alla genomandas av en a priori kritisk hållning. En annorlunda Derrida och ändå inte alls annorlunda, filosofen som iakttar det som annars undflyr oss som marginellt, som är för flyktigt eller svåråtkomligt.

Detta är Derrida: en stor filosof, en känslig, storsint och ansvarsfull medmänniska, en lysande författare. En sorglig men tacksamt omöjlig frånvaro.

\section{(C) Vasilis Papageorgiou}

